\title{
Selective thinning to enhance soil biodiversity in artificial black pine stands - what happens to mushroom fruiting?
}

\author{
Elena Salerni', Debora Barbato $\stackrel{\oplus}{\Perp}$, Cecilia Cazau², Lorenzo Gardin³, Gianni Henson', \\ Pamela Leonardi ${ }^{4}$, Antonio Tomao ${ }^{5}$, Claudia Perini ${ }^{1}$
}

Salerni E., Barbato D., Cazau C., Gardin L., Henson G., Leonardi P., Tomao

A., Perini C., 2020. Selective thinning to enhance soil biodiversity in artificial black pine stands - what happens to mushroom fruiting? Ann. For. Res. 63(2): 75-90.

Abstract As a man-induced disturbance of forest ecosystems, thinning may affect biodiversity and other related ecological functions including fungal dynamics. In this context, a multidisciplinary EU-Life project was established in 2014 to evaluate the application of selective thinning in two Pinus nigra plantations areas of the Apennines (Monte Amiata and Pratomagno, Tuscany, Italy). Selective thinning had the aim to improve stands stability and growth rates, taking also into account the various components of soil biodiversity (flora, fungi, mesofauna, nematodes, microarthropods and bacteria). Here we present mushroom fruiting patterns previous to treatment in 2014 and the effect following the application of forest management (selective thinning and traditional thinning from below) in 2018. Boxplots were used to graphically represent intra and inter annual variations in species richness and abundance, while Principal Coordinates Analyses and multi-response permutation procedures based on Bray-Curtis dissimilarity matrix were applied to evaluate turnover in species composition before the management and after 4 years. A significant reduction of fungal richness and abundance after 4 years thinning impact was lacking in both study areas, testifying a certain degree of resistance and/or resilience of mushroom fruiting to forest management-related anthropogenic disturbance. Considering each study site separately, Monte Amiata and Pratomagno did not show one uniform trend but differed significantly in their response to management: while in Pratomagno relevant inter-annual differences were present only in a few cases, an underlining significant variation both for species richness and abundance was registered in Monte Amiata for all treatment types among years (inter-annual variation) but not within each year (intra-annual variation). Only in Pratomagno turnover in species composition in selective thinning differed somewhat from the traditional treatment in 2018, showing that a process is underlying but still potentially masked by other variables. Due to the nature of macrofungi, a longer study period (more than 4 years post treatment impact) as well as the application of a more intense forest management, could be necessary to highlight and disentangle any possible trends in fungal fruiting in artificial stands.

Keywords: macrofungi, forest management, thinning, forest ecology, Pinus nigra. 
Addresses: ${ }^{1}$ Department of Life Sciences, University of Siena, Italy $\mid{ }^{2}$ Unione dei Comuni Pratomagno, Arezzo, Italy| ${ }^{3}$ SOILDATA Srl Soil territory environment, Florence, Italy $\mid{ }^{4}$ Department of Agricultural and Food Sciences, University of Bologna, Italy ${ }^{5}$ Department for Innovation in Biological Agrofood and Forest systems (DIBAF), University of Tuscia, Viterbo, Italy.

$\square$ Corresponding Author: Debora Barbato (debora.barbato87@gmail.com).

Manuscript received September 02, 2020; revised December 19, 2020; accepted December 23, 2020.

\section{Introduction}

Soil is a key factor in any environment, hosting an enormous variety and quantity of Earth's total biodiversity (Anderson 1975, Usher et al. 1979, Giller 1996, Andrén \& Balandreau 1999). For this reason, the maintenance of a vital soil biota represents an essential prerogative for many woodland ecosystems, as energy reaches the forest floor mainly through the degradation of organic matter and the recycling of vital elements found in animal and plant remains (Whitford 1996, Ekschmitt \& Griffiths 1998, Nielsen et al. 2011, Perini et al. 2017). Furthermore, a rich soil biodiversity guarantees the presence of vital habitats, the integrity of soil structure and water revenue, soil fertility and plant growth (Brussaard et al. 2004, 2007). Therefore, it is crucial for modern forestry management techniques to find a compromise between the economic needs of public and private entities, and the safeguard of biodiversity, both functionally and ethically. In the modern world, economic values must not surpass the needs of the environment.

In this context, fungi are a group of organisms with a high level of diversity (Hawksworth \& Lücking 2017). Soil fungi, for example, represent an important part of the soil microbial community: they are essential drivers of many ecosystem processes, such as soil organic matter (SOM) decomposition and nutrient release as well as plant nutrient uptake and production (Castaño et al. 2018). Furthermore, fungal fruit bodies, which constitute the main resource of an important socioeconomic activity based on mushroom picking for both recreational purposes and commercial markets, provide important provisioning and cultural ecosystem services to society (Pilz \& Molina 2002, Smith \& Read 2008, Bonet et al. 2014, Ágreda et al. 2015, Alday et al. 2017, Kucuker \& Baskent 2017, Tomao et al. 2017, Karavani et al. 2018).

The growing interest in mushroom production has led to the development of a promising new discipline over the past few decades: "mycosilviculture" defined as "the experimental science studying the interactions between the natural dynamics of forest ecosystems and management techniques with the aim of defining the best practices for the sustainability and profitability of fungal resources" (Tomao et al. 2017). The effect of thinning on fungal production is one of the most investigated silvicultural practice (Shaw et al. 2003, Salerni \& Perini 2004, Pilz et al. 2006, Egli et al. 2010, Kim et al. 2010, Salerni \& Perini 2010, Salerni et al. 2011, Bonet et al. 2012, Lin et al. 2015, Tahvanainrn et al. 2016, Leonardi et al. 2017, etc.). However, the impact on mushroom yield may be different for different fungal species. Several authors have found that thinning, particularly in coniferous stands, detains a positive effect on the fruit body yield of important marketable species (Lactarius spp., Boletus spp.), if it creates low medium density stands (Salerni \& Perini 2004, Bonet et al. 2012); by contrast, a negative effect has been reported for other target species such as Cantharellus spp., while a very highintensity thinning can also lead to a reduction 
in the fruit body yield (Tomao et al. 2017).

Regarding the influence of forest management on fungal diversity, many authors have found a decrease of ectomycorrhizal species richness after thinning (Lin et al. 2011, Lin et al. 2015, Maghnia et al. 2017). Even considering wood-inhabiting fungi, thinned stands showed a lower species richness compared to unmanaged stands, especially if intensive thinning is applied and most of the deadwood is removed (Müller et al. 2007). However, fungal diversity can be conserved or even increased using forestry practices if stand structural complexity and late-successional forest characteristics (e.g., vertically differentiated canopy layers release of snags and lying deadwood increase of small canopy gaps) are enhanced and low-impact logging operations are performed (Dove \& Keeton 2015, Tomao et al. 2020).

In this context, the mushroom fruiting in Pinus nigra plantations that underwent different types of thinning (selective thinning and the traditional thinning from below) in respect to control plots were studied. The main goal of a selective thinning was to create mechanically stronger populations that grew more efficiently, allowing more light penetration from the canopy to the forest undergrowth. Selective thinning also aimed to valorise sol components, potentially increasing the biodiversity of different taxonomic groups (Cantiani 2016).

Here the results of our observations on the mushroom fruiting before any action in 2014 and after 4 years of forest management in black pine plantations are presented. In particular, the specific aims of this research were: (i) to evaluate any possible impact on mushroom fruiting due to thinning in black pine plantations; (ii) to analyse the differences, if any, between selective and traditional thinning in enhancing and/or maintaining mushroom fruiting.

\section{Material and methods}

\section{Study area}

As already reported by Barbato et al. (2019), the study was carried out in two black pine plantations in Tuscany (central Italy). The first study site, called Monte Amiata, is in southern Tuscany (Castiglion d'Orcia Siena; $42^{\circ} 56^{\prime} 13.4^{\prime \prime} \mathrm{N} 11^{\circ} 37^{\prime} 41.0^{\prime \prime} \mathrm{E}$, mean elevation $780 \mathrm{~m}$ a.s.1.). The geological substrate was characterized by clay calcareous and marly lithofacies; soils were deep (OA-Bw-(Bg)-C profile), on average rich in organic matter in topsoil " $A$ " horizons (average organic matter content: $4.7 \%$ ), from scarcely gravelly to gravelly in depth, with a predominant clayey texture, from weakly to moderately calcareous. Average $\mathrm{pH}$ value was 7.6 while $\mathrm{C} / \mathrm{N}$ ratio detained a value of 10.5 (0-10 cm sampling depth in topsoil " $\mathrm{A}$ " horizon, excluding organic horizon (mean thickness of organic horizon: $3 \mathrm{~cm}$ )). Erosion processes (sheet rill or gully erosion) were lacking. From a taxonomic point of view (Soil Survey Staff 2014), the soils surveyed belong to the following families: Typic Eutrudepts, fine loamy, mixed, active, mesic for well-drained soils; Aquic Eutrudepts, fine, mixed, active, mesic if a clayey $\mathrm{Bg}$ horizon is present in the soil profile. Average annual temperature was $12.5^{\circ} \mathrm{C}$ (max: $21.7{ }^{\circ} \mathrm{C}$ in July; min: $4.5^{\circ} \mathrm{C}$ in January). Mean annual rainfall was $687 \mathrm{~mm}$ with November the rainiest month. The plantation was dominated by 44-year-old black pines, Pinus nigra Arnold (91.3\% and 97.3\% of total trees/ha and basal area respectively), followed by $<10 \%$ of Quercus pubescens Wild. and Quercus cerris L. (Cantiani 2016).

The second study site, Pratomagno, is in the north-eastern Tuscany (Pratomagno Arezzo; $43^{\circ} 35^{\prime} 55.3^{\prime \prime} \mathrm{N} 11^{\circ} 42^{\prime} 33.9^{\prime \prime} \mathrm{E}$, mean elevation $960 \mathrm{~m}$ a.s.1.). Lithology was quartz-feldspar sandstones alternating with siltstones and argillites; soils (O-A-Bw-R profile) were thin to moderately deep due to strong erosion, 
with high organic matter content in toposoil " $A$ " horizons (6.8\%); frequent presence of rock fragments such as coarse gravel, pebbles and stones throughout the profile, with a predominantly loose and sandy loam texture, not calcareous. Average soil $\mathrm{pH}$ value was 4.6 while $\mathrm{C} / \mathrm{N}$ ratio detained a value of 11.1 (0$10 \mathrm{~cm}$ sampling depth in topsoil "A" horizon, excluding organic horizon (mean thickness of organic horizon: $2.4 \mathrm{~cm}$ ). From a taxonomic point of view (Soil Survey Staff, 2014) the soils belong to Lithic Humudepts coarse loamy, mixed, superactive, mesic and Typic Humudepts coarse loamy, mixed, superactive, mesic.

Mean annual temperature was $10.5^{\circ} \mathrm{C}$ (max: $19{ }^{\circ} \mathrm{C}$ in July; min: $1.5^{\circ} \mathrm{C}$ in January) and mean annual rainfall was $997 \mathrm{~mm}$, with a maximum peak in autumn and a second peak in spring. The plantation was dominated by 57 years-old black pines $(83.4 \%$ of total trees/ha and $86 \%$ of total basal area/ha) with scattered Abies alba Mill. (especially at higher elevation) and occasionally broadleaf species such as Fagus sylvatica L., Fraxinus ornus L. and Quercus cerris L. (Cantiani 2016). Further information about study area is available at https://www. selpibio.eu/en.

\section{Experimental design}

In each site (i.e., Monte Amiata and Pratomagno) a stand of 20 ha dominated by black pine was selected. Stand features (basal area, tree density and gaps in the canopy cover) were kept as homogeneous as possible. In each stand nine-squared sectors of 1 ha were marked on the ground, of which three were established as control (no-thinning), three were treated with selective thinning and three with traditional thinning. The assignment of treatment type was done randomly with the only criteria that each treatment type was to be assigned three times throughout the overall stand (Cantiani 2016, Cantiani \& Marchi 2017). Three points were randomly selected in each sector for a total of 27 points per site and 54 in the whole study. Then several concentric plots of variable size, ranging from $10 \mathrm{~m}$ radius for mycological analysis to $15 \mathrm{~m}$ radius for dendrometric and structural assessment, were defined in the field using the spatial coordinates of the random points as the centers of the circular plots (Cantiani \& Marchi 2017). Further information about sampling design is available at https://www.selpibio.eu/en.

\section{Soil sampling methodology}

Following Italian standard methodologies (Costantini, 2007), soil general attributes (stony surface, rockiness, cracks, topographical characters) and main characteristics of each soil horizon (such as color, rock fragments, granulometry, redoximorphic features and depth of horizons) were described in each plot using a soil auger. In each drilled plot, a soil sample of about $1 \mathrm{~kg}$ was collected to the depth of mineral horizon ( $0-10 \mathrm{~cm}$ excluding organic horizon) for chemical-physical analysis. At the same depth, another soil sample was collected for bulk density by a core of known volume $\left(100 \mathrm{~cm}^{3}\right)$ (Pagliai 1997). Furthermore, for each study area (Monte Amiata and Pratomagno) a subset of three soil profiles by soil horizons up to the depth of about 1 meter were collected in order to better characterize some aspects (structure, porosity, pedogenetic features, etc.) not immediately appreciable by drilling; other additional parameters (cation exchange capacity and acidity) were analyzed too.

\section{Silvicultural treatments}

In the SelPiBio LIFE project two different types of thinning have been applied: a traditional thinning and a selective thinning. The traditional thinning is a light thinning from below, where less than $20 \%$ of basal area is removed and only dominated trees are cut. This type of thinning is very common in evenaged stands dominated by Pinus nigra in Italy. 
The selective thinning is a moderate thinning (basal area removal around 30\%), where not only dominated but also co-dominant and dominant trees are removed. In the selective thinning, tree removal is not uniformly distributed within the stand but is located around a set of "candidate trees". Furthermore, the average number of candidate trees should be around 100 trees per hectare. This number represents the optimum average density for a 100 years old pine forest (Cantiani 2016). Candidate trees are chosen based on a set of characteristics which includes: (i) the tree vigour (trees should belong to the stand dominant layer and therefore must have diameters and heights above average stand parameters); (ii) the degree of mechanical stability (i.e., a slenderness coefficient lower than 90); (iii) a high crown depth, (iv) a symmetrical crown, (v) the lack of mechanical and/or pathological damage. Around these candidate trees, all the competitor trees, either belonging to dominant or co-dominant layer, are removed. From a structural point of view, selective thinning aims at increasing both horizontal (opening of micro gaps around the candidate trees) and vertical (breaking the monotony of canopy layer) structural diversity.

Selective thinning, although widely used in many forest systems such as oak, beech and mixed stands (e.g., Boncina et al. 2007, Di Salvatore et al. 2013, Manetti et al. 2020), has been rarely applied in artificial pine forests (Marchi et al. 2018).

A summary of main dendrometric attributes of the stands before and after thinning is reported in Tab. 1 .

\section{Survey methodology}

In each plot, all fruit bodies larger than $1 \mathrm{~mm}$ were counted and fully harvested, as proposed by Arnolds (1981). This survey method has been widely used to study macrofungal diversity in different forest ecosystems worldwide (Kranabetter et al. 2005, Oria-deRueda et al. 2010, Abrego \& Salcedo 2014, Dejene et al. 2017, Suominen et al. 2019).

Sampling was performed every two weeks during the period of highest fungal production (autumn) and once in spring, before (2014) and four years after forest thinning (2018). Once per season also some hypogeous ascomycete have been collected thanks to the presence of trained dogs. Species identification was performed with the usual morphological techniques, general analytical keys and monographs (Salerni \& Perini 2010). Each species was classified in different trophic categories on the basis of field direct observations and following Arnolds et al. (1995). Most of the collected specimens are conserved in Herbarium Universitatis Senensis (SIENA). The fungal nomenclature follows CABI list (http://www. indexfungorum.org/Names/NAMES.ASP) updated at May 2018.

Table 1 Dendrometric attributes of the stands before and after thinning in the two study sites (Monte

Amiata and Pratomagno). Thinning intensity is calculated as percentage of basal area removal

\begin{tabular}{|c|c|c|c|c|c|c|}
\hline \multirow[t]{2}{*}{ Study site } & \multirow[t]{2}{*}{ Treatment } & \multirow{2}{*}{$\begin{array}{c}\text { Number of trees } \\
\text { before thinning } \\
\text { N/ha }\end{array}$} & \multirow{2}{*}{$\begin{array}{c}\text { Number of trees } \\
\text { after thinning } \\
\text { N/ha }\end{array}$} & \multirow{2}{*}{$\begin{array}{c}\text { Basal area } \\
\text { before thinning } \\
\mathrm{m}^{2} / \mathrm{ha}\end{array}$} & \multirow{2}{*}{$\begin{array}{l}\text { Basal area } \\
\text { after thinning } \\
\mathrm{m}^{2} / \mathrm{ha}\end{array}$} & \multirow{2}{*}{$\begin{array}{c}\text { Thinning } \\
\text { intensity } \\
\% \text { of } \\
\text { removed } \\
\text { basal area }\end{array}$} \\
\hline & & & & & & \\
\hline Monte Amiata & Control & 1064 & 1063 & 41.84 & 41.84 & 0.0 \\
\hline Monte Amiata & Selective & 1004 & 674 & 48.05 & 33.42 & 30.4 \\
\hline Monte Amiata & Traditional & 1025 & 745 & 43.15 & 35.21 & 18.4 \\
\hline Pratomagno & Control & 1003 & 1003 & 63.97 & 63.97 & 0.0 \\
\hline Pratomagno & Selective & 896 & 600 & 61.45 & 42.23 & 31.3 \\
\hline Pratomagno & Traditional & 965 & 681 & 67.72 & 55.41 & 18.2 \\
\hline
\end{tabular}




\section{Statistical analyses}

For each study site (Monte Amiata and Pratomagno), the diversity patterns of the observed mushrooms were evaluated in terms of richness (number of species), abundance (number of fruit bodies) and turnover in species composition, before (2014) and after management (2018) impact. Trophic structure was also evaluated, showing differences in total species richness and percent relative proportion of fungal trophic groups. Dominant guilds were identified in six groups of trophic modes: $\mathrm{M}$ - mycorrhizal; $\mathrm{Sh}$ - humus saprotroph; Sw - wood saprotroph; Sl - litter saprotroph; P - parasite; Sc - coprophytic saprotroph.

Boxplots were used to graphically represent the communities and further studied with the Kruskal-Wallis and Wilcoxon test for paired samples to identify significant differences between the pre (2014) and post (2018) treatment year, for each single management type (traditional thinning, selective thinning and control) (inter annual differences) and between all three treatment types within each year (intra annual differences). Turnover in species composition was also evaluated using the Principal Coordinates Analysis (PCoA) with the Bray-Curtis dissimilarity matrix on abundance data, for each study site separately. Following ordination, multi-response permutation procedures (MRPP) were used to test whether the assemblage structure differed significantly between the treatments in each year. The procedure was performed with 999 permutations based on Bray-Curtis distance. All statistical analyses were performed using "ggplot2" "gridExtra" and "vegan" packages in software R (R Core Team 2018).

\section{Results}

A total of 266 species and 19538 fruit bodies were recorded: 197 species were identified from Monte Amiata (Tab. S1 in Supplementary
Materials) whilst 141 were found in Pratomagno (Tab. S2 in Supplementary Materials). 125 were exclusively detected in Monte Amiata, 69 in Pratomagno, while 72 species (marked with * in Tab. S1 and Tab. S2) were shared by both study sites. The most abundant and frequent species (for all sites, years and treatment types) were Galerina marginata with 2004 fruit bodies, Inocybe geophylla with 459, Baeospora myosura with 191 and Suillus granulatus with 168.

When considering the effects of the selective thinning, the species that appeared less or were absent in the pre-treatment 2014 plots acquired some degree of frequency and abundance following the 2018 selective thinning. Such species were Hebeloma sacchariolens, Lepiota castanea, Cortinarius rigens and Gymnopus confluens for Monte Amiata (Tab. S1); Hygrophoropsis aurantiaca, Rhodocollybia butyracea, Hypholoma fasciculare and Gymnopilus penetrans for Pratomagno (Tab. S2). Other species also showed some degree of response to the selective thinning, but their presence in other treatment types makes them less relevant to the selective and more to management in general. In fact, many species were abundant and frequent for every treatment type, such as Pholiota gummosa and Lyophyllum semitale for Monte Amiata (Tab. S1) or Mycena epipterygia and Tricholomopsis rutilans for Pratomagno (Tab. S2), while some appeared in response to treatment in general and were not present prior such as Mycena niveipes and M. purpureofusca (Tab. S1 and $\mathrm{S} 2$ ).

The effects of management practices were also evaluated comparing the differences in the trophic structure of observed mushrooms in 2014 and 2018, for each treatment type separately (Tab. 2).

Concerning total species richness for the main fungal trophic groups (Tab. 2), the selective thinning registered changes for both study sites, where the total mycorrhizal species (M) and humus saprotrophs (Sh) increased in 
Monte Amiata and decreased in Pratomagno, comparing pre- and post-treatment years. Effects were also registered in the other trophic groups, where parasites $(\mathrm{P})$ wood saprotrophs ( $\mathrm{Sw}$ ) and litter saprotrophs ( $\mathrm{Sl}$ ) varied (Tab. 2).

For Monte Amiata, the trend for the selective treatment was also present for the traditional thinning, where an increase both in M (20 species in 2014, 27 in 2018) and Sh (18 species in 2014, 45 species in 2018) was recorded; in control, total $\mathrm{M}$ species richness remain unvaried between years (20 species both in 2014 and 2018), while Sh increased as happened in the other two management types (30 in 2014, 47 in 2018) (Tab. 2).

For Pratomagno, $\mathrm{M}$ species met a decrease in traditional thinning as simultaneously happened in all the other treatment types (selective thinning and control; Tab. 2); traditional management practice had a different effect respect to selective thinning, at least concerning Sh species number, which increased (13 in 2014, 19 in 2018). The same trend as selective thinning was found in control, where a slightly decrease in Sh was recorded (25 in 2014, 24 in 2018).

Considering percent proportion of fungal trophic groups (Fig. 1), in Monte Amiata (Fig. 1 a,b) only a minor increase of Sh and a decrease of $\mathrm{M}$ were detected in 2018 plots treated with selective and traditional thinning. However, this change was also recorded in unmanaged control plots. Meanwhile, the rate of fungal trophic groups recorded a drastic change after forest management in Pratomagno study site (Fig. 1c,d): in both treatments the percentage of mycorrhizal species massively decreased, even halving in the plots affected by traditional treatment (Fig. 1d). In this case, control plots remained more or less unvaried in their proportion of fungal trophic groups between years.

Overall variation in species richness and abundances at plot level were graphically evaluated with boxplots for both Monte Amiata and Pratomagno study sites, further tested for significant results.

For Monte Amiata (Fig. 2a), significant results concerning the variation in species richness for each treatment type between years were identified (selective $\mathrm{p}<0.01$, traditional $\mathrm{p}<0.01$, control $\mathrm{p}<0.01$ ), but no other significant results were collected for the overall differences within 2014 and 2018, showing a more or less similar pattern. For Pratomagno (Fig. 2b), slightly significant results were only identified for the variation of species richness in selective thinning between pre- and post-treatment years $(\mathrm{p}=0.01)$, with no other significant results collected.

Table 2 Total species richness of fungal trophic groups in Monte Amiata and Pratomagno study sites before (2014) and after (2018) management practices (Control, Selective and Traditional thinning)

\begin{tabular}{|c|c|c|c|c|c|c|c|c|c|c|c|c|}
\hline \multirow{3}{*}{$\begin{array}{l}\text { Study site } \\
\text { Management practices } \\
\text { Year }\end{array}$} & \multicolumn{6}{|c|}{ Monte Amiata } & \multicolumn{6}{|c|}{ Pratomagno } \\
\hline & \multicolumn{2}{|c|}{ Control } & \multicolumn{2}{|c|}{ Selective } & \multicolumn{2}{|c|}{ Traditional } & \multicolumn{2}{|c|}{ Control } & \multicolumn{2}{|c|}{ Selective } & \multicolumn{2}{|c|}{ Traditional } \\
\hline & 2014 & 2018 & 2014 & 2018 & 2014 & 2018 & 2014 & 2018 & 2014 & 2018 & 2014 & 2018 \\
\hline Total species richness & 69 & 89 & 63 & 98 & 49 & 97 & 59 & 50 & 72 & 53 & 65 & 43 \\
\hline Mycorhizal richness (M) & 20 & 20 & 22 & 25 & 20 & 27 & 27 & 18 & 30 & 15 & 40 & 13 \\
\hline Humus saprotroph richness (Sh) & 30 & 47 & 24 & 48 & 18 & 45 & 25 & 24 & 29 & 23 & 13 & 19 \\
\hline Wood saprotroph richness (Sw) & 15 & 19 & 15 & 21 & 8 & 22 & 7 & 8 & 11 & 15 & 12 & 11 \\
\hline Litter saprotroph richness (Sl) & 2 & 3 & 2 & 3 & 2 & 2 & & & 1 & & & \\
\hline Parasitic richness $(\mathrm{P})$ & 2 & & & & 2 & & & & 1 & & & \\
\hline $\begin{array}{l}\text { Coprophytic saprotroph } \\
\text { richness }(\mathrm{Sc})\end{array}$ & & & & 1 & 1 & & & & & & & \\
\hline
\end{tabular}



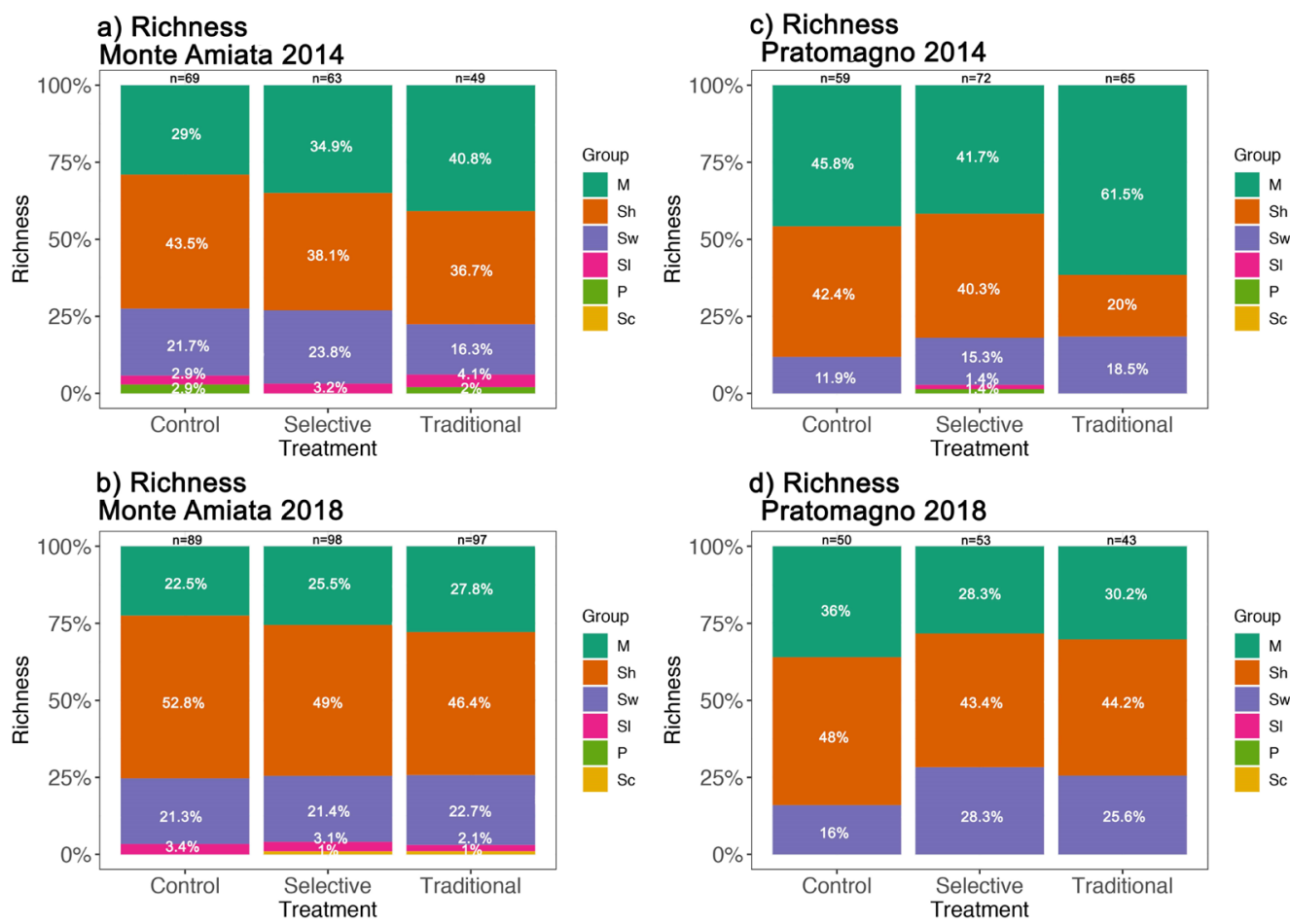

Figure $1 \mathbf{a}, \mathbf{b}, \mathbf{c}, \mathbf{d}$ Barcharts of fungal trophic groups before and after treatments

Barcharts showing percentage proportion of fungal trophic groups $(\mathrm{M}-$ mycorrhiza; $\mathrm{Sh}$ - humus saprotroph; Sw - wood saprotroph; Sl - litter saprotroph; P - parasite; Sc coprophytic saprotroph) in Monte Amiata (a, b) and Pratomagno (c, d) study sites before (2014) and after (2018) management practices (Control, Selective and Traditional thinning)

A similar trend to that of the species richness was also registered for the species abundance for Monte Amiata (Fig. 3a), as significant results were identified for the variation of each treatment type between years (selective $\mathrm{p}<0.01$, traditional $\mathrm{p}<0.01$, control $\mathrm{p}<0.01)$ and not for the overall 2014 and 2018 species abundance trend. For Pratomagno (Fig. 3b), significant differences were recorded only for control $(\mathrm{p}=$ 0.01 ) treatments between years, but not for the overall differences within 2014 and 2018.

Concerning the turnover in macrofungal communities, Monte Amiata (Fig. 4a) showed an initial similarity in 2014. Following 2018, the overall specific composition shifted in a way that the two polygons, including respectively the 2014 and 2018 plots, did not overlap. However, no difference between treatment types was recorded within the last year of post treatment, thus sharing similar specific composition.

Pratomagno (Fig. 4b) bared an initial diversity, as the ellipsis overlap only partially and have a more diverse specific composition. Respect to Monte Amiata, Pratomagno selective thinning plots significantly differed from the communities found in control and traditional treatment plots in 2018, as confirmed by the clear separation of selective thinning ellipses from the other treatments in PCoA (Fig. 4b) and by MRPP analysis results $(p=0.02)$ (Tab. 3). All the other comparisons were not statistically significant. 

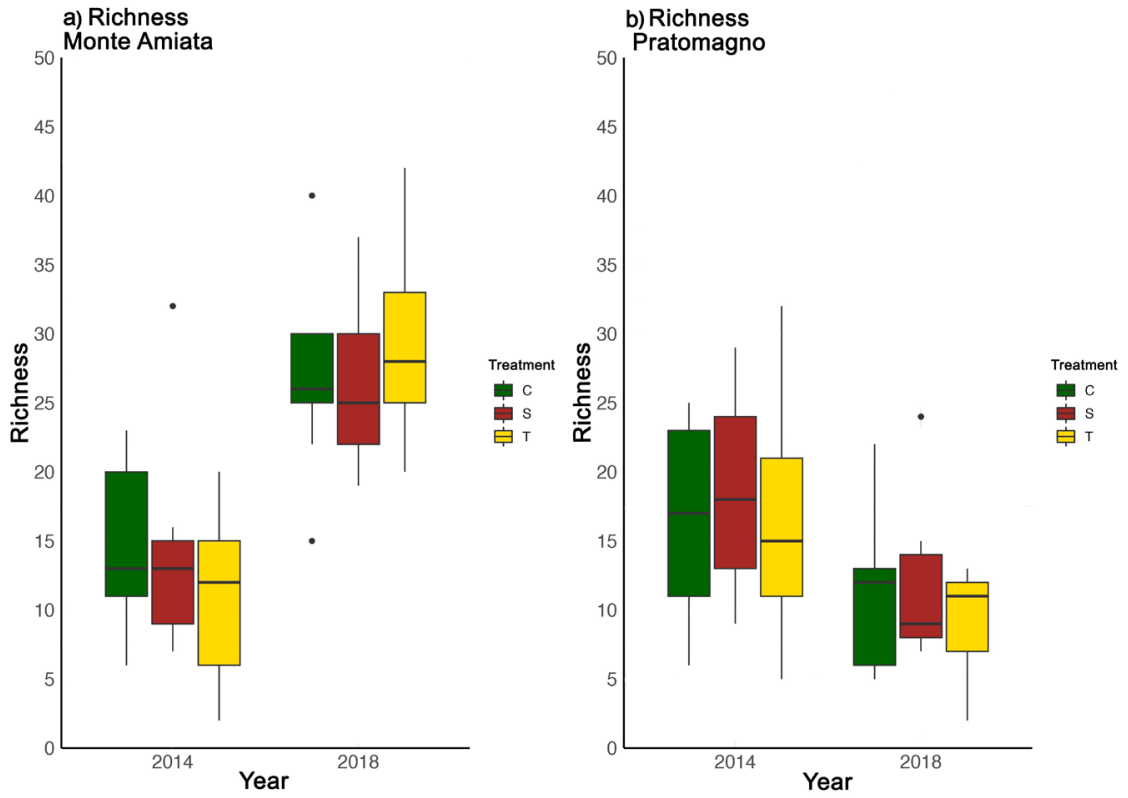

Figure 2 a,b Macrofungal species richness before and after treatments

Boxplot of species richness in Monte Amiata (a) and Pratomagno (b) before (2014) and after (2018) management practices $(\mathrm{C}=\mathrm{Control}, \mathrm{S}=$ Selective thinning, $\mathrm{T}=$ Traditional thinning)
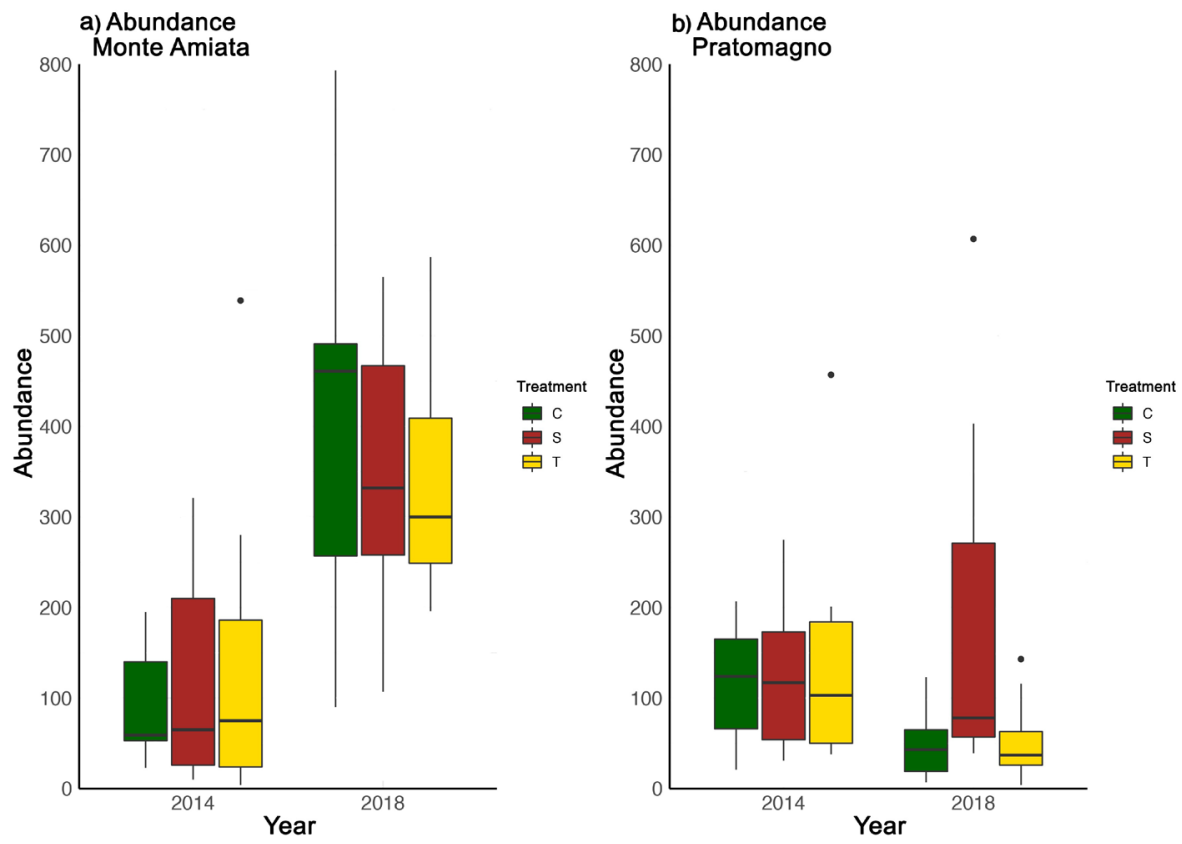

Figure 3 a,b Macrofungal species abundance before and after treatments

Boxplots of species abundance in Monte Amiata (a) and Pratomagno (b) before (2014) and after (2018) management practices $(\mathrm{C}=\mathrm{C}$ Control, $\mathrm{S}=$ Selective thinning, $\mathrm{T}=$ Traditional thinning) 

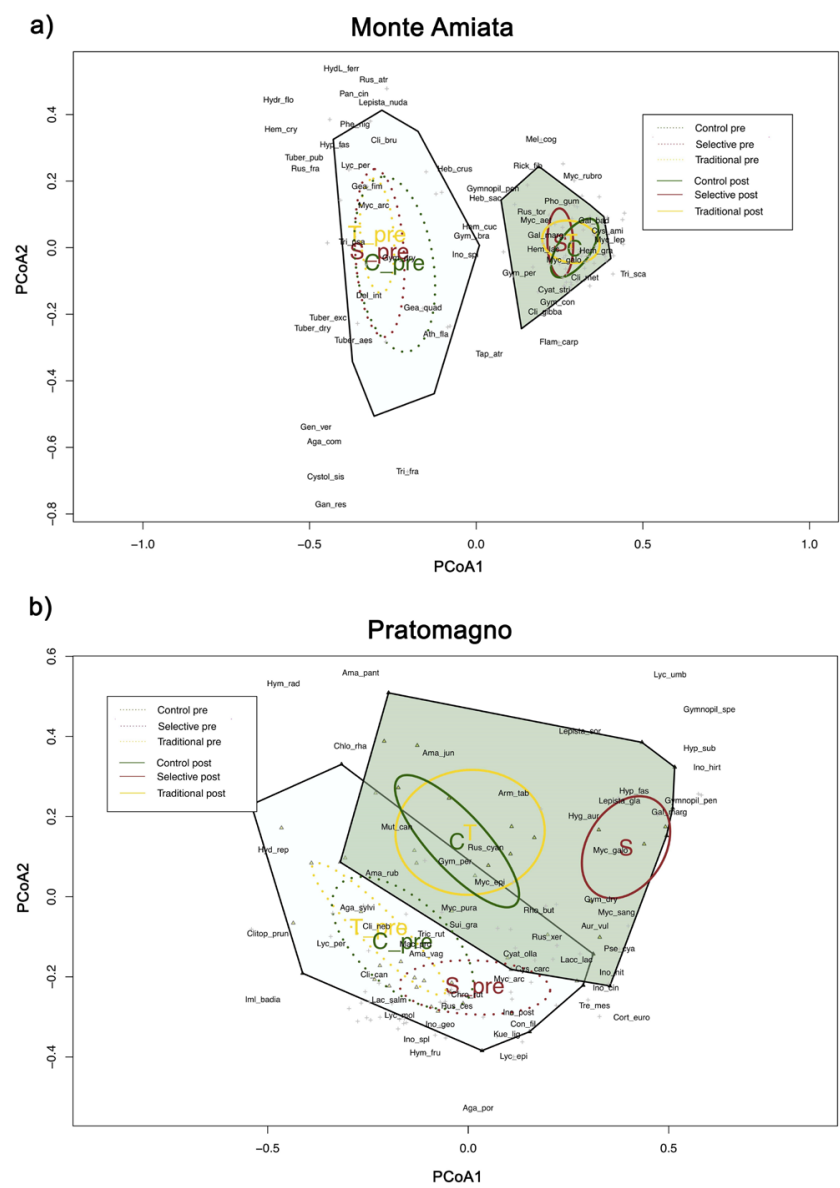

Figure 4 a,b Turnover in macrofungal species composition before and after treatments

Principal Coordinates Analysis (PCoA) for the plots relative to Monte Amiata (a) and Pratomagno (b) study sites before (2014) and after (2018) management practices (Control, Selective and Traditional thinning). The ellipses represent ordination confidence intervals (95\%). The lines represent the minimum convex polygon including respectively the 2014 (light blue polygon) and 2018 plots (green polygon). Abbreviations correspond to the first alphabet letters of species names in Table S1 (Monte Amiata) and Table S2 (Pratomagno)

\section{Discussion}

This study, included in the wider SelPiBioLife project, was finalized in analysing the effects of the selective thinning on mushroom fruiting in the Pinus nigra plantations of the study areas of Monte Amiata and Pratomagno, Tuscany, Italy.

The main aim was to shed light on the mycosilviculture and its benefits, considering parameters such as richness, abundance and turnover in species composition before and after management impact.

Results confirmed previous studies, which highlighted how pine forests maintain lower specific species richness in macrofungi than deciduous forests but with higher abundance in fruit bodies (Lin et al. 2015). 
Table 3 Results of multiple-response permutation procedures (MRPP) testing the null hypothesis of no significant differences in macrofungal species composition among three treatment types (Control, Selective and Traditional thinning) for each year (pre-treatment 2014; post-treatment 2018) and study sites (Monte Amiata and Pratomagno) separately

\begin{tabular}{|c|c|c|c|c|c|}
\hline & $\mathrm{N}$ & Delta & $\begin{array}{l}\text { Chance corrected within } \\
\text { group agreement A }\end{array}$ & $\begin{array}{l}\text { Significance of } \\
\text { delta }(\alpha=0.05)\end{array}$ & $\begin{array}{c}\text { Number of } \\
\text { permutations }\end{array}$ \\
\hline \multicolumn{6}{|c|}{ Monte Amiata 2014} \\
\hline -Control & 9 & 0.891 & & & \\
\hline -Selective & 9 & 0.869 & 0.003 & 0.326 & 999 \\
\hline -Traditional & 9 & 0.916 & & & \\
\hline \multicolumn{6}{|c|}{ Monte Amiata 2018} \\
\hline -Control & 9 & 0.710 & & & \\
\hline -Selective & 9 & 0.740 & 0.004 & 0.300 & 999 \\
\hline -Traditional & 9 & 0.739 & & & \\
\hline \multicolumn{6}{|c|}{ Pratomagno 2014} \\
\hline -Control & 9 & 0.772 & & & \\
\hline -Selective & 9 & 0.816 & 0.009 & 0.198 & 999 \\
\hline -Traditional & 9 & 0.810 & & & \\
\hline \multicolumn{6}{|c|}{ Pratomagno 2018} \\
\hline -Control & 9 & 0.885 & & & \\
\hline -Selective & 9 & 0.815 & 0.023 & 0.017 & 999 \\
\hline -Traditional & 9 & 0.919 & & & \\
\hline
\end{tabular}

Along with the frequent and abundant species, the presence of entities that only appeared or were more present after the treatment in the 2018 selective thinning plots can be regarded as a possible sign of how the selective thinning influenced the macrofungal communities, as these species grow mainly under trees but not necessarily in closed forest environments and prefer open or altered areas such as clearings walkways and field borders (Candusso \& Lanzoni 1990, Antonín \& Noordeloos 1997, Beker et al. 2016). The degree of this effect, however, is still uncertain as the two study areas did not show one uniform trend but differed significantly in their response to management, as confirmed by boxplots for richness and abundance: while in Pratomagno relevant inter-annual differences were present only in a few cases, in Monte Amiata an underlining significant variation both for species richness and abundance was registered for all treatment types among years (inter-annual variation) but not within each year (intra-annual variation), where all treatments resulted to change together in a homogenous way. Interestingly, both 2014 and 2018 communities in control plots changed in the same way as the other treatment types did. This may be explained by the disturbance caused by field sampling, as it is known that any form of interference (such as trampling or other recreational activities) can create repercussions in the mushroom fruiting as forest management techniques, such as thinning, do (Waltert et al. 2002, Egli et al. 2006, Tomao et al. 2017). As reported in some studies, mushroom harvesting does not appear to affect fruitbody production per se, but trampling caused by successive mushroom pickers throughout a given forest area, may negatively affect fruitbody production (Egli et 
al. 1990, Norvell 1995, Egli et al. 2006).

Also concerning variation in composition of observed mushrooms, differences mainly had an inter-annual nature: species composition for each treatment changed over time but not within the same year, where all treatments showed a uniform trend of variation. The only significant difference, as confirmed by MRPP results, was recorded in Pratomagno, where the selective thinning bared a distinctly different composition and abundance of species in 2018 respect to traditional and control, which still shared similar communities.

As seen in other studies, forest management performed with thinning has an important and evident effect on fungal fruiting, affecting richness abundance and turnover in species composition (Salerni \& Perini 2004, Savoie \& Largeteau 2011, Santos-Silva et al. 2011, Lin et al. 2015, Tomao et al. 2017, Tomao et al. 2020), but each effect must be contextualized to site-specific microhabitat condition.

In our case, any lack of significant reduction of fungal richness and abundance 4 years after thinning impact seemed to testify a certain degree of resistance and/or resilience of mushroom fruiting to the forest managementrelated anthropogenic disturbance applied. In this regard, Castaño et al. (2018) report a substantial stability of species richness and diversity of soil fungi after thinning, when substrates of saprotrophic species are not affected by the thinning operations and enough host trees and functional roots from thinned trees are retained.

However, such response can be partially obscured and masked by the presence of other factors, possibly more dominant than thinning itself. It is well known that fungal production can be influenced by different environmental variables (Boddy et al. 2014), also resulting in a complex network of interactions with other taxonomic groups (Barbato et al. 2019). Among soil variables soil $\mathrm{pH}$ is typically one of the most important driver of global fungal richness and many fungal groups typically exhibit diverse preferences for site-specific edaphic conditions (Tedersoo et al. 2014). For example, most truffles species share common ecological features and usually peak in terms of abundance and productivity at neutral/high soil pH (e.g., Mello et al. 2006, Ponce et al. 2014). This could be the reason for the almost complete absence of many truffle species in the acid soils of Pratomagno study area.

Also, climate itself can play a big role in influencing the presence of macrofungi, controlling therefore the growth of the fruit bodies through the effect of precipitation, temperature, soil moisture and humidity (Martínez de Aragón et al. 2007, Savoie \& Largeteau 2011, Martínes-Peña et al. 2012, Lin et al. 2015, Karavani et al. 2018). This is the reason why the selective thinning had a bigger effect on Pratomagno communities respect to Monte Amiata, or at least it was more evident. One possible explanation is that local climate influenced the mushroom fruiting of Monte Amiata more than thinning techniques did. When an optimal balance for fruit body growth was present, the selective thinning did show different effects compared to both traditional forest thinning and control plots.

Other studies have highlighted how the effects on mushroom fruiting take longer to register than other woodland biota (Pilz et al. 2006, Egli et al. 2010, Robinson \& Williams 2011, Baral et al. 2015, Tomao et al. 2017). The effect of a management technique usually starts with an initial decrease due to a physiological response to human impact and disturbance, followed by an increase in species, registering up to six years after the initial impact (Pilz et al. 2006). For the same reason, more time is probably needed to distinguish initial trends from possible permanent changes (Robinson \& Williams 2011), along with a positive trend between the thinning, the temporal response of the tree growth and the reaction of fungal communities (Egli et al 2010). Moreover, each species reacts differently not only to management type but also to the intensity 
applied (Egli et al. 2010, Savoie \& Largeteau 2011, Lin et al. 2015, Tomao et al. 2017).

The age and health of the tree is another important factor to be considered when planning forest management. Older and weaker trees generally produce smaller photosynthetic outputs and therefore are not able to sustain mycorrhizal species in the same way as a younger and stronger tree would (Bonet et al. 2004, Egli et al. 2010, MartínesPeña et al. 2012). This potentially influences the growth of these mycorrhizal communities, meaning that forests made up of stronger trees may produce more mushrooms yield (Bonet et al. 2004), a key factor to be considered when planning forest management. From literature it is known that selective thinning is able to favour stronger trees with advantageous positions in the canopy, improving the exposure to light and empowering their growth (Cantiani 2016); for the same reason selective thinning may also increase mycorrhizal growth and consequently productivity. Variation of the canopy, which controls micro-climatic factors, and the competition of ground level shrubbery with the macrofungi community are other parameters that vary according to the intensity of forest management applied (Santos-Silva et al. 2011).

\section{Conclusions}

Concerning mushroom fruiting, whether the selective thinning is to be preferred over the traditional thinning remains unclear through the lens of this research, as the trends that appeared did not produce decisive responses in the time range considered. The lack of significant results is possibly due to the nature of macrofungi, in terms of slower reactions to management impact and different speciesbased characteristics: two species may react in opposite ways to the same perturbation while other two may react differently to various degrees of change. A mix of positive and negative reactions from different varieties can cause indecisive results. In any case, the lack of significant reduction of fungal diversity (richness and abundance) after both traditional and selective thinning 4 years after the treatment showed how mushroom fruiting may be very resistant and/or resilient to forest managementrelated anthropogenic disturbance.

It is possible to hypothesise that a longer study period would grant more definitive findings, as well as testing different degrees of treatment intensity. With the absence of a visible trend, it is impossible to establish whether an increase follows. The inclusion in future observations of climatic factors and other parameters such as soils' chemical and physical properties, canopy covering and ground level shrubbery, that possibly interact negatively with certain entities, would make for a more complete mycosilviculture management.

\section{Acknowledgements}

This work was supported by the EU's LIFE+ "Nature and biodiversity" program through the SelPiBio LIFE project (Innovative silvicultural treatments to enhance soil biodiversity in artificial black pine stands i.e., LIFE13BIO/ IT/000282) for demonstration of innovative silvicultural treatments in artificial black pine stands.

\section{References}

Abrego N., Salcedo I., 2014. Response of wood-inhabiting fungal community to fragmentation in a beech forest landscape. Fungal Ecol 8: 18-27.

Ágreda T., Águeda B., Olano J.M., Vicente-Serrano S.M., Fernández-Toirán M., 2015. Increased evapotranspiration demand in a Mediterranean climate might cause a decline in fungal yields under global warming. Glob Change Biol 21: 3499-3510.

Alday L.G., Bonet J.A., Oria-de-Rueda J.A., Martínez de Aragón J., Aldea J., Martín-Pinto P., de-Miguel S., Hernández-Rodríguez M., Martínez-Peña F., 2017. Record breaking mushroom yields in Spain. Fungal Ecol 26: 144-146.

Anderson JM., 1975. The enigma of soil animal species diversity. In: Vaněk J., (ed.), Progress in Soil Zoology. Proceedings of the 5th International Colloquium on Soil Zoology Held, 17-22 September 1973, Prague, Czech 
Republick, pp. 51-58.

Andrén O., Balandreau J., 1999. Biodiversity and soil functioning - from black box to can of worms? Appl Soil Ecol 13: 105-108.

Antonín V., Noordeloos ME., 1997. A monograph of Marasmius, Collybia and related genera in Europa (part 2: Collybia, Gymnopus, Rhodocollybia, Crinipellis, Chaetocalathus and additions to Marasmiellus). IHWVERLAG, $256 \mathrm{p}$.

Arnolds E., 1981. Ecology and coenology of macrofungi in grassland and moist heatland in Drenthe the Netherlands. Biblioteca Mycologica, $410 \mathrm{p}$.

Arnolds E., Kuyper T.A., Noordeloos ME., 1995. Overzicht van de paddestoelen in Nederland [Overview of the mushrooms in the Netherlands]. Nederlandse Mycologische Vereniging, 872 p.

Baral S., Thapa-Magar KB., Karki G., Devkota S., Shrestha B.B., 2015. Macrofungal diversity in communitymanaged sal (Shorea robusta) forests in central Nepal. Mycology 6(3-4): 151-157.

Barbato D., Perini C., Mocali S., Bacaro G., Tordoni E., Maccherini S., Marchi M., Cantiani P., De Meo I., Bianchetto E., Landi S., Bruschini S., Bettini G., Gardin L., Salerni E., 2019. Teamwork makes the dream work: disentangling cross-taxon congruence across soil biota in black pine plantations. Sci Total Environ 656: 659669

Beker J.H., Eberhardt U., Vesterholt J., 2016. Hebeloma (Fr.) P. Kumm. (Vol. 14 - Fungi Europaei). Edizioni Tecnografica, $1218 \mathrm{p}$.

Boddy L., Büntgen U., Egli S., Gange A., Heegaard E., Kirk P., Mohammad A., Kauserud H., 2014. Climate variation effects on fungal fruiting. Fungal Ecol 10: 2033.

Boncina A., Kadunc A., Robic D., 2007. Effects of selective thinning on growth and development of beech (Fagus sylvatica L.) forest stands in south-eastern Slovenia. Ann For Sci 64(1): 47-57.

Bonet J.A., Fischer C.R., Colinas C., 2004. The relationship between forest age and aspect on the production of sporocarps of ectomycorrhizal fungi in Pinus sylvestris forests of the central Pyrenees. Forest Ecol Manag 203: 157-175.

Bonet J.A., De-Miguel S., de Aragón J.M., Pukkala T., Palahí M., 2012. Immediate effect of thinning on the yield of Lactarius group deliciosus in Pinus pinaster forests in Northeastern Spain. Forest Ecol Manag 265: 211-217.

Bonet J.A., González-Olabarria J.R., Martínez de Aragón J., 2014. Mushroom production as an alternative for rural development in a forested mountainous area. $\mathrm{J} \mathrm{Mt}$ Sci 11(2): 535-543.

Brussaard L., Kuyper T.W., Didden W.A.M., de Goede R.G.M., Bloem J., 2004. Biological soil quality from biomass to biodiversity - Importance and resilience to management stress and disturbance. In: SchjØnning P., Elmholt S., Christensen B.T., (eds.), Chapter: 9 Managing soil quality: Challenges in modern agriculture. CABI Publishing, pp.139-161.

Brussaard L., de Ruiter P.C., Brown G.G., 2007. Soil biodiversity for agricultural sustainability. Agr Ecosyst Environ 121: 233-244.

Candusso M., Lanzoni G., 1990. Lepiota s.1. (Vol. 4 - Fungi Europaei). Libreria Editrice Giovanna Biella, 743 p.

Cantiani P., 2016. Il diradamento selettivo. Accrescere stabilità e biodiversità in boschi artificiali di pino nero. Manuale tecnico SelPiBioLife [LIFE13 BIO/IT/000282]. Compagnia delle Foreste, Arezzo, Italy, 62 p.

Cantiani P, Marchi M., 2017. A spatial dataset of forest mensuration collected in black pine plantations in central Italy. Ann For Sci 74(3): 50.

Castaño C., Alday JG., Lindahl B.D., Martínez de Aragón J., de-Miguel S., Colinas C., Parladé J., Pera J., Bonet J.A., 2018. Lack of thinning effects over inter-annual changes in soil fungal community and diversity in a Mediterranean pine forest. Forest Ecol Manag 424: 420-427.

Costantini E.A.C., 2007. Linee guida dei metodi di rilevamento e informatizzazione dei dati pedologici. CRA-ABP, Firenze, Italy, 296 p.

Dejene T., Oria-de-Rueda J.A, Martín-Pinto P., 2017. Fungal diversity and succession following stand development in Pinus patula Schiede ex Schltdl. \& Cham. plantations in Ethiopia. Forest Ecol Manag, 395: 9-18.

Di Salvatore U., Ferretti F., Cantiani P., Paletto A., De Meo I., Chiavetta U., 2013. Multifunctionality assessment in forest planning at landscape level. The study case of Matese Mountain Community (Italy). Ann Silvic Res 37: 45-54

Dove N.C., Keeton W.S., 2015. Structural complexity enhancement increases fungal species richness in northern hardwood forests. Fungal Ecol 13: 181-192.

Egli S., Ayer F., Chatelain F., 1990. Der Einfluss des Pilzsammelns auf die Pilzflora [The influence of mushroom picking on the mushroom flora]. Mycologia Helvetica 3(4): 417-428.

Egli S., Peter M., Buser C., Stahel W., Ayer F., 2006. Mushroom picking does not impair future harvestsresults of a long-term study in Switzerland. Biol Conserv 129(2): 271-276.

Egli S., Ayer F., Peter M., Eilmann B., Rigling A., 2010 Is forest mushroom productivity driven by tree growth? Results from a thinning experiment. Ann Forest Sci 67: 509.

Ekschmitt K., Griffiths B.S., 1998. Soil biodiversity and its implications for ecosystem functioning in a heterogeneous and variable environment. Appl Soil Ecol 10: 201-215.

Giller P.S., 1996. The diversity of soil communities the poor man's tropical rainforest. Biodivers Conserv 5: 135-168.

Hawksworth D.L., Lücking R., 2017. Fungal diversity revisited: 2.2 to 3.8 million species. In: Heitman J., Howlett B., Crous P., Stukenbrock E., James T., Gow N.A.R. (eds), The Fungal Kingdom. ASM Press, Washington DC, USA, pp. 79-95.

Karavani A., De Cáceres M., Martínez de Aragón J., Bonet 
JA., de-Miguel S., 2018. Effect of climatic and soil moisture conditions on mushroom productivity and related ecosystem services in Mediterranean pine stands facing climate change. Agr Forest Meteorol 248: 432-440.

Kim M.S., Klopfenstein N.B., McDonald G.I., 2010. Effects of forest management practices and environment on occurrence of Armillaria Species. Journal of Korean Forest Society 99(2): 251-257.

Kranabetter J.M., Friesen J., Gamiet S., Kroeger P., 2005. Ectomycorrhizal mushroom distribution by stand age in western hemlock-lodgepole pine forests of northwestern British Columbia. Can. J. For. Res. 35(7): 1527-1539.

Kucuker D.M., Baskent E.Z., 2017. Impact of forest management intensity on mushroom occurrence and yield with a simulation-based decision support system. Forest Ecol Manag 389: 240-248.

Leonardi P., Graziosi S., Zambonelli A., Salerni E., 2017. The economic potential of mushrooms in an artificial Pinus nigra forest. Italian Journal of Mycology 46: 48-59.

Lin W.R., Chen W.C., Wang P.H., 2011. Effects of forest thinning on diversity and function of macrofungi and soil microbes. Sydowia 63(1): 67-77.

Lin W.R., Wang P.H., Chen M.C., Kuo Y.L., Chiang P.N., Wang M.K., 2015. The impacts of thinning on the fruiting of saprophytic fungi in Cryptomeria japonica plantations in central Taiwan. Forest Ecol Manag 336: 183-193.

Maghnia F.Z., Sanguin H., Abbas Y., Verdinelli M., Kerdouh B., El Ghachtouli N., Lancellotti E., Bakkali Yakhlef S.E., Duponnois R., 2017. Impact du mode de gestion de la subéraie de la Maâmora (Maroc) sur la diversité des champignons ectomycorhiziens associés à Quercus suber [Impact of the management method of the Maâmora cork grove (Morocco) on the diversity of ectomycorrhizal fungi associated with Quercus suber]. C R Biol 340(5): 298-305.

Manetti M.C., Becagli C., Bertini G., Cantiani P., Marchi M., Pelleri F., Sansone D., Fabbio G., 2020. The conversion into high forest of Turkey oak coppice stands: methods, silviculture and perspectives. iForest 13: 309-317. - doi: 10.3832/ifor3483-013

Marchi M., Paletto A., Cantiani P., Bianchetto E., De Meo I., 2018. Comparing thinning system effects on ecosystem services provision in artificial black pine (Pinus nigra JF Arnold) forests. Forests, 9(4): 188.

Martínez-Peña F., de-Miguel S., Pukkala T., Bonet JA., Ortega-Martínez P., Aldea J., Martínez de Aragón J., 2012. Yield models for ectomycorrhizal mushrooms in Pinus sylvestris forests with special focus on Boletus edulis and Lactarius group deliciosus. Forest Ecol Manag 282: 63-69.

Martínez de Aragón J., Bonet J.A., Fischer C.R., Colinas C., 2007. Productivity of ectomycorrhizal and selected edible saprotrophic fungi in pine forests of the prePyrenees mountains Spain: Predictive equations for forest management of mycological resources. Forest Ecol Manag 252: 239-256.

Mello A., Murat C., Bonfante P., 2006. Truffles: much more than a prized and local fungal delicacy. FEMS
Microbiol Lett, 260(1): 1-8.

Müller J., Engel H., Blaschke M., 2007. Assemblages of wood-inhabiting fungi related to silvicultural management intensity in beech forests in southern Germany. Eur J For Res 126: 513-527.

Nielsen U.N., Ayres E., Wall D.H., Bardgett R.D., 2011. Soil biodiversity and carbon cycling: a review and synthesis of studies examining diversity - function relationships. Eur J Soil Sci 62: 105-116.

Norvell L., 1995. Loving the chanterelle to death? The tenyear Oregon chanterelle project. McIlvainea 12(1): 6-25.

Oria-de-Rueda J.A., Hernández-Rodríguez M., MartínPinto P., Pando V., Olaizola J., 2010. Could artificial reforestations provide as much production and diversity of fungal species as natural forest stands in marginal Mediterranean areas? Forest Ecol Manag 260(2): 171-180.

Pagliai M., 1997. Metodi di analisi fisica del suolo. Franco Angeli, Milano. $400 \mathrm{p}$

Perini C., Barbato D., Bianchetto E., Mocali S., De Meo I., Cantiani P., Salerni E., 2017. Soil biota and innovative forest management: a Life Project. In: Proceedings of the "European Council for Conservation of Fungi and International Mycological Association". 1-6 October 2017 Ohrid, Republic of Macedonia, pp. 48-49.

Pilz D., Molina R., 2002. Commercial harvests of edible mushrooms from the forests of the Pacific Northwest United States: issues management and monitoring for sustainability. Forest Ecol Manag 155(1): 3-16.

Pilz D., Molina R., Mayo J., 2006. Effects of thinning young forests on chanterelle mushroom production. J Forest 104: 9-14.

Ponce R.A., Ágreda T., Águeda B., Aldea J., MartínezPeña F., Modrego M.P., 2014. Soil physical properties influence "black truffle" fructification in plantations. Mycorrhiza 24:55-64

R Development Core Team., 2018. R: A Language and Environment for Statistical Computing. R Foundation for Statistical Computing, Vienna, Austria. URL: http:// cran. rproject.org/.

Robinson R.M., Williams M.R., 2011. Forestcheck: the response of epigeous macrofungi to silviculture in jarrah (Eucalyptus marginata) forest. Aust Forestry 74(4): 288-302.

Salerni E., Perini C., 2004. Experimental study for increasing productivity of Boletus edulis s.l. in Italy. Forest Ecol Manag 201: 161-170.

Salerni E., Perini C., 2010. Macrofungal communities in Italian fir woods - short term effects of silviculture and its implications for conservation. Cryptogamie Mycol 31: 251-283.

Salerni E., Baglioni F., Perini C., 2011. Valorizzazione della produzione di Tuber aestivum Vittad. in tartufaie naturali presenti nel Monte Amiata e nel Monte Cetona. Micologia Italiana 40(1): 44-62.

Santos-Silva C., Goncalves A., Louro R., 2011. Canopy cover influence on macrofungal richness and sporocarp production in montado ecosystems. Agroforest Syst 82: 149-159.

Savoie J.M., Largeteau M.L., 2011. Production of edible 
mushrooms in forests: trends in development of a mycosilviculture. Applied Microbiol Biot 89: 971-979.

Shaw P.J.A., Kibby G., Mayes J., 2003. Effects of thinning treatment on an ectomycorrhizal succession under Scots pine. Mycol Res 107(3): 317-328.

Smith S.E., Read D.J., 2008. Mycorrhizal Symbiosis 3rd edn. Academic Press, London, 800 p.

Soil Survey Staff., 2014. Keys to soil taxonomy. 12th ed. USDA - Natural Resources Conservation Service, Washington, DC.

Suominen M., Junninen K., Kouki J., 2019. Diversity of fungi in harvested forests 10 years after logging and burning: Polypore assemblages on different woody substrates. Forest Ecol Manag 446: 63-70.

Tahvanainen V., Miina J., Kurttila M., Salo K., 2016. Modelling the yields of marketed mushrooms in Picea abies stands in eastern Finland. Forest EcolManag 362: 79-88.

Tedersoo L., Bahram M., Põlme S., Kõljalg U., Yorou N.S., Wijesundera R. et al., 2014. Global diversity and geography of soil fungi. Science, 346(6213).
Tomao A., Bonet J.A., Martínez de Aragón J., de-Miguel S., 2017. Is silviculture able to enhance wild forest mushroom resources? Current knowledge and future perspectives. Forest Ecol Manag 402: 102-114.

Tomao A., Bonet J.A., Castaño C., de-Miguel S., 2020. How does forest management affect fungal diversity and community composition? Current knowledge and future perspectives for the conservation of forest fungi. Forest Ecol Manag 457: 117678.

Usher M.B., Davis P., Harris J., Longstaff B., 1979. A profusion of species? Approaches towards understanding the dynamics of the populations of microarthropods in decomposer communities. In: Anderson RM., Turner BD., Taylor LR., (eds.), Population dynamics. Blackwell Scientific Publications, pp. 359-384.

Waltert B., Wiemken V., Rusterholz H.P., Boller T., Baur B., 2002. Disturbance of forest by trampling: Effects on mycorrhizal roots of seedlings and mature trees of Fagus sylvatica. Plant Soil 243: 143-154.

Whitford W.G., 1996. The importance of the biodiversity of soil biota in arid ecosystems. Biodivers Conserv 5: 185-195. 